\title{
GCMS, phytochemicals and antioxidant activities of in vitro callus extracts of Strobilanthes kunthiana (Nees) T. Anderson ex Benth: An endemic plant of Acanthaceae
}

\section{R. Prabakaran* and E. Kirutheka}

PG and Research Department of Botany. PSG College of Arts \& Science. Coimbatore - 641014. India. *Email: raju.prabakaran@gmail.com.

\begin{abstract}
Strobilanthes kunthiana (Neelakurinji) is an endemic and underexploited plant belongs to the Family Acanthaceae. The aim of our study was to evaluate phytochemical analysis, GC-MS analysis and antioxidant activity of in vitro callus extract of Strobilanthes kunthiana. In this present study the phytochemical analysis of various extract of $S$. kunthiana in vitro callus were studied. Phytochemical analysis confirmed the presence of alkaloids, flavonoids, glycosides, saponins, tannins, steroids, terpenoids and phenols in the methanolic extract comparing to the other extracts. In this study GC-MS analysis revealed the presence of 10 bioactive phytochemical compounds were identified in the methanolic extract. The prevailing compounds were 9,12-octadecadienoic acid (Z,Z) (50.32\%), hexadecanoic acid, methyl ester (20.69\%), 9-octadecenoic acid (Z)-,methyl ester (10.45\%), heptadecanoic acid, 16-methyl-, methyl ester (5.78\%), 2,6-bis(1,1-dimethylethyl)-4-methyl phenol (4.70\%). 3-methyl-2-ketobutyric acid tbdms (2.79\%), 2,2,3,4-tetramethyl-5-hexen-3-ol (2.41\%), N-(tertbutoxycarbonyl)-2-(4-methoxyphenyl) allylamine (1.06\%), cyclotrisiloxane, hexamethyl (0.94\%), benzenesulfonamide $(0.87 \%)$. The antioxidant property was evaluated for methanol and ethanolic extract by DPPH method. The higher percentage of inhibition (79.23 \pm 0.37 ) was observed in $250 \mu \mathrm{g} / \mathrm{mL}$ of ethanol extract followed by $(90.35 \pm 0.54)$ methanolic extract against the standard ascorbic acid (91.25 \pm 0.33$)$. The results show that the methanolic extract possesses more antioxidant activity than ethanol. The plant $S$. kunthiana may be exploited as a source of natural antioxidant and as herbal alternatives for various disorders.
\end{abstract}

Keywords: In vitro callus; Phytochemical; GC-MS analysis; DPPH; Antioxidant.

\section{Introduction}

India has a rich culture of medicinal herbs which includes about
Received

April 30, 2018

Accepted

August 21, 2018

Released

August 31, 2018

Full Text Article

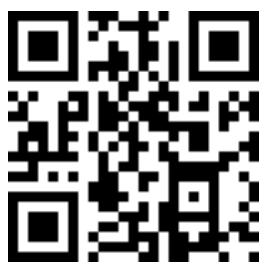

ORCID

(D) $0000-0002-3106-4328$

R. Prabakaran

(D) 0000-0001-8608-8856

E. Kirutheka
8,000 species of known medicinal plants and about more than 2,000 species and has a vast geographical area with high potential abilities for Ayurvedic, Unani, 
and Siddha medicines but only very few have been studied chemically and pharmacologically for their potential medicinal values (Guptha et al., 2005). The phytochemical produced from medicinal herbs are curative constituents for several diseases. The plant natural compounds used as alternative sources of medicines continuous to play major roles in the general wellness of people all over the world. Plants have been provided mankind with sources of medicinal agents, natural products, once serving as the source of all drugs (Balandrin et al., 1993). It plays an important role in searching for novel drugs based on their new modes of pharmacological actions. This action may due to the presence of carbohydrates, carbohydrate derivatives, gums, mucilage's, pectin's, glycosides tannins, phenolic compounds, lipids, fixed and volatile oils, resins, alkaloids, terpenoids flavonoids, steroids etc.

Nowadays there was a number of dramatic advances in analytical techniques including TLC, UV, NMR and GC-MS that were powerful tools for separation identification and structure determination of phytochemicals. GCMS is the most commonly used techniques for the identification and quantification purpose. The unknown organic compounds in a complex mixture can be determined by interpretation and also by matching the spectra with reference spectra (Hites, 1997).

A variety of these plant secondary metabolites have been reported to act as antioxidants and amongst them phenolic compounds form a major group. Antioxidants may have defined as free radicals scavengers which protect cells against damage.

Strobilanthes kunthiana (Nees) T. Anderson ex Benth locally known as Neelakurinji belongs to the family Acathaceae. It is a shrub that grow abundantly in the Shola forest of Western Ghats in South India (Paulsamy et al, 2007; Moylan et al, 2004) at 13002400 metres above Mean Sea Level (MSL) and endemic to Western Ghats. The plant belongs to the genus Strobilanthes which was first scientifically described by Christian Gottfried Daniel Nees von Esenbeck in India in the 19th century (Anonymous I and II). The plant grows $2 \mathrm{~m}$ tall, bushy with reddish stout branches, hairless and glabrous. Leaves are base acute, margin crenate- serrate, dense hispid except veins above, floccose hispid below. The inflorescence spike branched or unbranched with many flowers. Bracts are elliptic to ovate, white villous, midrib not prominent. Bracteolate which are lanes shape, $10 \mathrm{~mm}$ long shorter than calyx. Calyx are lobed, divided almost half from the base, floccose- villous, linear-lanceolate. Corolla tubular ventricose portion, hispid inside and glabrous outside. Androecium are staminal filaments not grooved, pilose hispid. Gynoecium style $15 \mathrm{~mm}$ ovary hairy at the apex. Fruit oblong, 4 seeded (Augustine et al., 2017).

S. kunthiana is well known to possess both ornamental and medicinal properties. The abundant source of unique active components shows antiinflammatory, anti-osteoarthritic (Desu et al., 2011), analgestic properties (Desu et al., 2012) anticancer activity and antioxidant (Singh et al., 2014), antibioflim activity (Everlyne et al., 2016), enzyme inhibitor, central nervous depressant activity (Rajasekaran et al., 2000), antigiardial activity (Singh et al., 2012) antifungal, antibacterial, antiseptic, hypocholesterolemic 5-alpha reductase inhibitor, antimicrobial, cytotoxicity, protect skin against UV (Everlyne et al., 2015).

The aim of our study was to evaluate phytochemical analysis, GC-MS analysis and antioxidant activity of in vitro callus extract of Strobilanthes kunthiana. 


\section{Materials and methods}

The application of biotechnological principles for the establishment of phytochemical, GC-MS analysis, antioxidant activity of in vitro callus of Strobilanthes kunthiana have been studied by following methods as given below.

\section{Plant material and surface disinfestation}

The plant material was collected in seed from Yercaud hills at altitude of $\pm 1623 \mathrm{~m}$, in Eastern Ghats, Selam Dt., Tamil Nadu, India. Seeds were collected and used for various experiments for developing the protocol for explant preparation and regeneration. The collected seeds were washed with running tap water for $15 \mathrm{~min}$ and then washed with Tween 20 detergent solution $(5 \% \mathrm{v} / \mathrm{v})$ for $5 \mathrm{~min}$. Surface sterilization of seeds was followed by rinsing with sterile distilled water 3 or 4 times to remove trace of detergent, rinsing in $70 \%$ ethanol for $30 \mathrm{~s}$ and finally treated with mercuric chloride $(0 \%-12 \% \mathrm{~W} / \mathrm{V}) \quad\left(\mathrm{HgCl}_{2}\right)$ for $3 \mathrm{~min}$ duration.

\section{Culture medium and culture conditions}

A culture medium containing MS salt supplemented with macro elements, micro elements, iron, vitamins, amino acid and 3\% sucrose (Hi-Media, India) was used. The $\mathrm{pH}$ of the medium was adjusted to 5.8 by $1 \mathrm{~N} \mathrm{NaOH}$ or $1 \mathrm{~N} \mathrm{HCl}$ after adding the growth regulators. The media were steam sterilized in an autoclave under $15 \mathrm{psi}$ and $121{ }^{\circ} \mathrm{C}$ for $20 \mathrm{~min}$. All of the cultures were

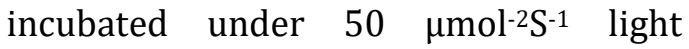
provided by cool while fluorescent lamp for a photo period of $16 \mathrm{~h}$ at $25 \pm 2{ }^{\circ} \mathrm{C}$.

\section{Callus initiation}

Node, internodes and leaf explants from in vitro grown plants from seeds were used as primary explants. The explants were cultured on MS medium supplemented with various concentrations of growth regulators (BAP, 2, 4 D and NAA). Twenty explants were used for each culture. The percent of explants responding for callus induction, nature of callus and number of days taken for callus induction were recorded after 40 days (Plate $1 \mathrm{~A}-\mathrm{C}$ ).

\section{PLATE-1}
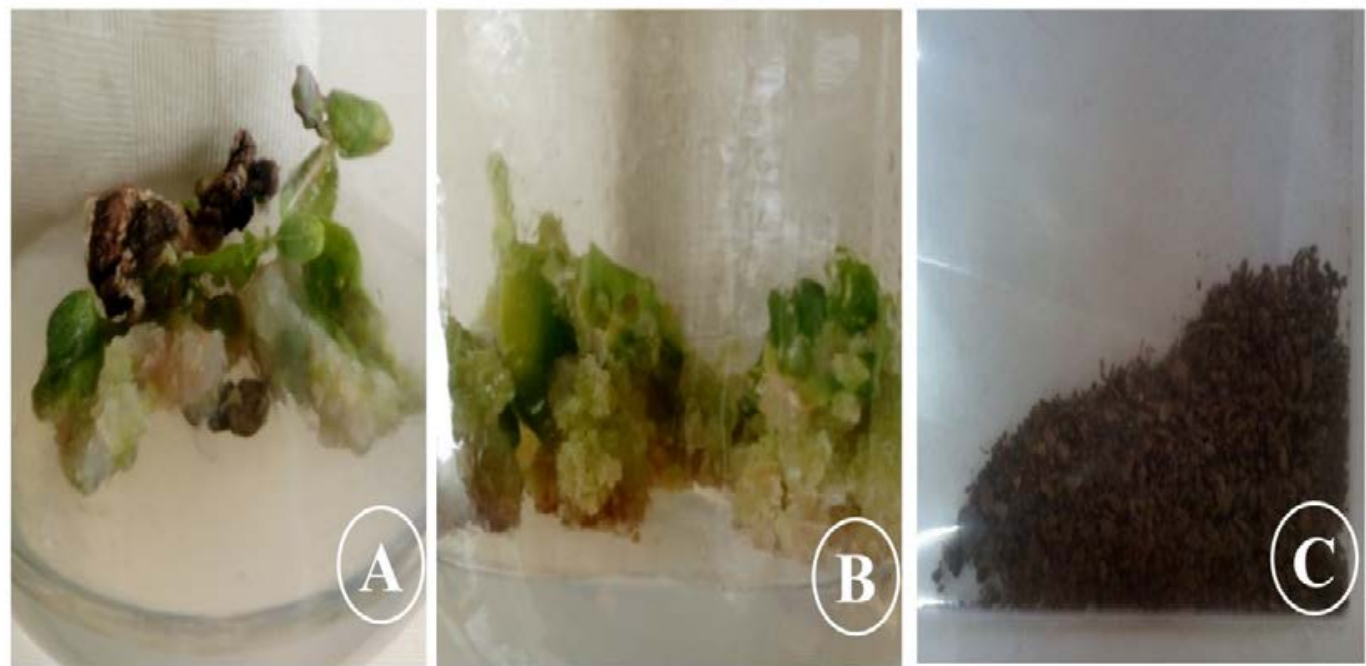

Plate 1-Callus initiation: A) Initial stage, B) Final stage, C) Callus powder. 


\section{Callus frequency}

The percentage of callusing was recorded at the end of fifth week.
Frequency of callus induction was calculated as shown below and was represented as percentage

$$
\text { Frequency of response }(\%)=\frac{\text { Number of explants responded }}{\text { Total number of explants cultured }} \times 100
$$

\section{Preparation of extract}

The leaf derived 30 days old in vitro callus collected from our laboratory was air dried and powdered and stored in room temperature. One gram of callus sample in $5 \mathrm{ml}$ of ethanol, methanol, chloroform, petroleum ether and water were added separately. It was then kept on a rotary shaker at $150-220 \mathrm{rpm}$ for 24 h. The extracts were centrifuged at 2500rpm, the supernatant was collected. This were repeated for three times.

\section{Phytochemical studies}

The in vitro callus extracts were subjected to preliminary phytochemical tests to determine the group of secondary metabolites present in the plant material. Condensed extracts were used for preliminary screening of phytochemicals such as alkaloids, steroids, and phenols (Gibbs, 1974); glycosides, terpenoids and saponins (Ayoola et al., 2008); tannins (Treare and Evans, 1985); flavonoids (Peach and Tracey, 1956).

\section{Gas chromatography mass spectrometry analysis}

The shade-dried $2 \mathrm{~g}$ powder of in vitro callus subjected to extraction in Soxhlet extractor with $70 \%$ methanol for $70 \mathrm{~h}$ (extract yield: 9\%) and extract is collected. The collected extract is evaporated to dryness and stored at $4{ }^{\circ} \mathrm{C}$ until used.

The GC-MS analysis was carried out using a Clarus 500 Perkin-Elmer (Auto system XL) Gas Chromatograph equipped and coupled to a mass detector Turbo mass gold-Perkin Elmer Turbomass 5.2 spectrometer with an
Elite-5MS (5\% diphenyl/95\% dimethyl polysiloxane), $30 \mathrm{~m} \times 0.25 \mu \mathrm{m}$ DF of capillary column. The instrument was set to an initial temperature of $110{ }^{\circ} \mathrm{C}$, and maintained at this temperature for $2 \mathrm{~min}$. At the end of this period the oven temperature was rose up to $280{ }^{\circ} \mathrm{C}$, at the rate of an increase of $5{ }^{\circ} \mathrm{C} / \mathrm{min}$, and maintained for $9 \mathrm{~min}$. Injection port temperature was ensured as $200{ }^{\circ} \mathrm{C}$ and helium flow rate as one $\mathrm{mL} / \mathrm{min}$. The ionization voltage was $70 \mathrm{eV}$. The samples were injected in split mode as 10:1. Mass spectral scan range was set at 45-450 (m/z). Using computer searches on a NIST Version-Year 2011 were used MS data library and comparing the spectrum obtained through GC-MS compounds present in the plants sample were identified.

\section{Antioxidant activity}

The present investigations on in vitro callus extracts of $S$. kunthiana was carried out through antioxidant activity, were attempted.

\section{activity}

DPPH Radical Scavenging

The antioxidant activity of the methanolic and ethanolic extract of in vitro $S$. kunthiana callus extract was measured on the basis of the scavenging activity of the stable 2,2-diphenyl-1picryl hydrazyl (DPPH) free radical according to the method described by (Brand-Williams et al., 1995). $1.5 \mathrm{~mL}$ of $0.1 \mathrm{mM}$ DPPH solution in methanol was mixed with $1 \mathrm{~mL}$ of methanol and ethanol extract solution of varying concentrations $(50,100,150,200$ and $250 \mu \mathrm{g} / \mathrm{mL}$ ). Corresponding blank 
sample were prepared and L-ascorbic acid $(50-250 \mu \mathrm{g} / \mathrm{mL})$ was used as reference standard. Mixer of different concentration 50-250 $\mu \mathrm{g} / \mathrm{mL}$ methanolic and ethanolic and $1.5 \mathrm{~mL}$ DPPH solution was used as control. The reaction was carried out in triplicate and the decrease in absorbance was measured at $517 \mathrm{~nm}$ after $30 \mathrm{~min}$ in dark using UV-Vis spectrophotometer. The inhibition percentage was calculated using the following formula.

$$
\text { Inhibition } \%=\text { Ac-As } / \text { Ac } \times 100
$$

Where: Ac is the absorbance of the control As is the absorbance of the sample

\section{Result}

In the present study preliminary phytochemical analysis of methanol, ethanol, petroleum ether, chloroform and water extracts of Strobilanthes kunthiana leaf callus are presented in the table 1. Qualitative phytochemical analysis of this in vitro leaf callus confirm the presence of various secondary metabolites. According to chemical test methanolic extract showed positive test with all the compounds like alkaloids, Flavonoids, Glycosides, Saponins, tannins, steroids, Terpenoids and Phenols. Both ethanolic and petroleum ether extracts showed the absence of glycosides and saponins. Followed by chloroform extract showed positive test with alkaloids, glycosides, saponins, tannins, steroids and phenols. Similarly, water extract showed positive to alkaloids, glycosides, tannins, steroids and phenols. It was concluded that the in vitro leaf callus of $S$. kunthiana extract contains important constituent for pharmacological activities.

Table 1. Qualitative phytochemical analyses of S.kunthiana methanol in vitro callus extract.

\begin{tabular}{|c|c|c|c|c|c|c|}
\hline & \multirow{2}{*}{$\begin{array}{c}\text { Phytochemical } \\
\text { test in methanol } \\
\text { extract }\end{array}$} & \multicolumn{5}{|c|}{ Inference } \\
\hline & & Methanol & Ethanol & $\begin{array}{c}\text { Petroleum } \\
\text { Ether }\end{array}$ & Chloroform & Water \\
\hline 1 & Alkaloids & + & + & + & + & + \\
\hline 2 & Flavonoids & + & + & + & - & - \\
\hline 3 & Glycosides & + & - & - & + & + \\
\hline 4 & Saponins & + & - & - & + & - \\
\hline 5 & Tannins & + & + & + & + & + \\
\hline 6 & Steroids & + & + & + & + & + \\
\hline 7 & Terpenoids & + & + & + & - & - \\
\hline 8 & Phenols & + & + & + & - & - \\
\hline
\end{tabular}

The components present in the methanolic extract of callus of S. kunthiana were identified by GCMS (Figure 1). The ten compounds were detected belonging to various group like linoleic acid, palmitic acid methyl ester, unsaturated fatty methyl ester, stearic acid, lipophilic, allyl amino butane and phenolic compound. The active principle with their retention time (RT), Compound name, molecular formula, molecular weight, peak area (\%), and activities related with medicinal uses are given in the (Table 2). The result 
revealed that the presence of 9,12octadecadienoic acid (Z,Z) (linoleicacid) $(50.32 \%)$ shows highest percentage followed by hexadecanoic acid, methyl ester (palmitic acid methyl ester) (20.69\%), 9-octadecenoic acid (Z),methyl ester (unsaturated fatty methyl ester) $(10.45 \%)$, heptadecanoic acid, 16methyl-, methyl ester (stearic acid)
(5.78\%), 2,6-bis(1,1-dimethylethyl)-4methyl phenol (lipophilic) (4.70\%), 3methyl-2-ketobutyric acid tbdms (2.79\%), 2,2,3,4-tetramethyl-5-hexen-3ol (2.41\%), N-(tert-butoxycarbonyl)-2(4-methoxyphenyl) allylamine (allyl amino butane) (1.06\%), cyclotrisiloxane, hexamethyl (phenolic compound) $(0.94 \%)$, benzenesulfonamide $(0.87 \%)$.

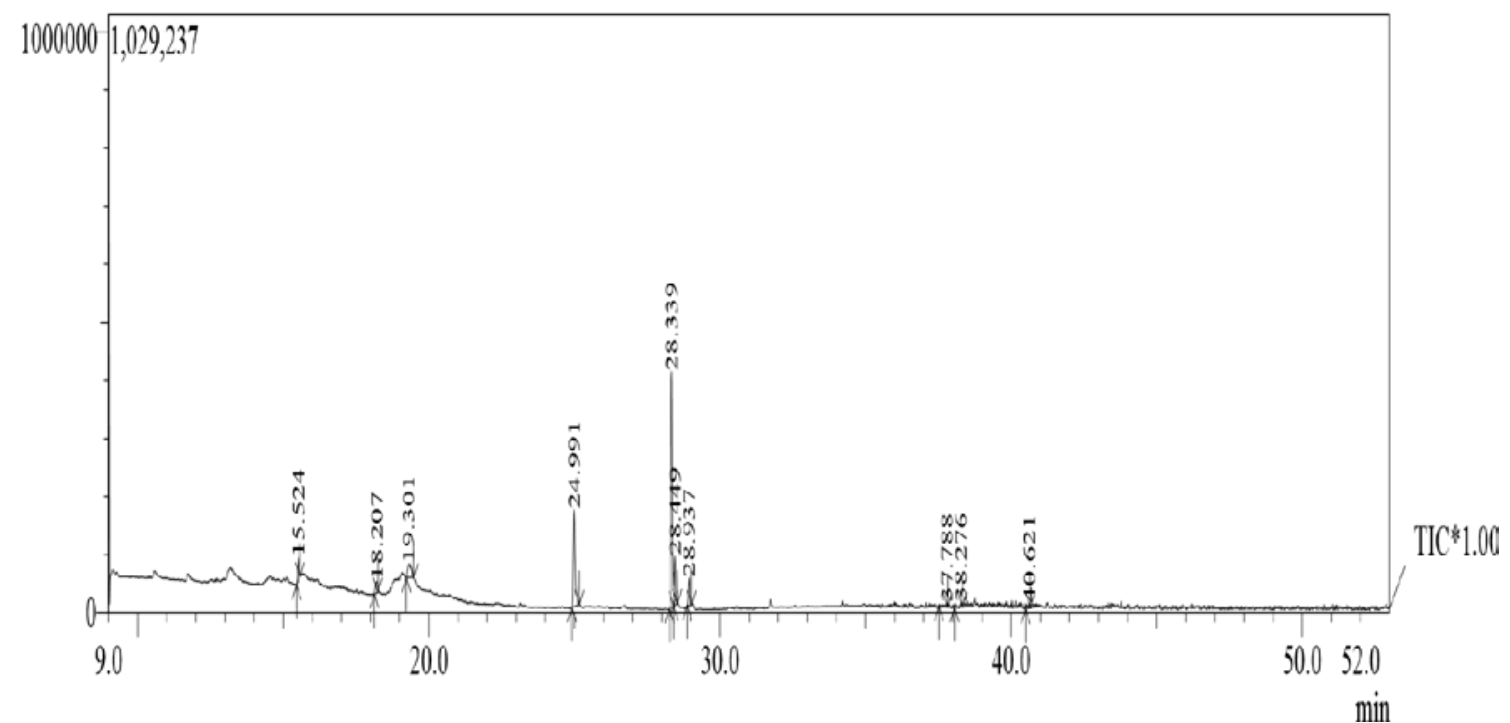

Figure 1. Phytochemicals identified through GCMS in methanolic extracts of in vitro callus of S. kunthiana.

Table 2. Compounds identified in the methanolic in vitro callus extract of S. kunthiana.

\begin{tabular}{|c|c|c|c|c|c|c|c|}
\hline & RT & Compound & Formula & $\begin{array}{c}\text { Molecular } \\
\text { weight }\end{array}$ & $\begin{array}{l}\text { Peak } \\
\text { area }\end{array}$ & Structure & Medicinal uses \\
\hline 1 & 15.524 & $\begin{array}{c}\text { 2,6-bis(1,1- } \\
\text { dimethylethyl)- } \\
\text { 4-methyl phenol }\end{array}$ & $\mathrm{C}_{15} \mathrm{H}_{24} \mathrm{O}$ & 220 & 4.70 & & $\begin{array}{c}\text { Antioxidant } \\
\text { (Ibtissem et al., 2010) }\end{array}$ \\
\hline 2 & 18.207 & $\begin{array}{c}2,2,3,4- \\
\text { Tetramethyl-5- } \\
\text { hexen-3-ol }\end{array}$ & $\mathrm{C}_{10} \mathrm{H}_{20} \mathrm{O}$ & 156 & 2.41 & & No report \\
\hline 3 & 19.301 & $\begin{array}{l}\text { 3-Methyl-2- } \\
\text { ketobutyric acid } \\
\text { tbdms }\end{array}$ & $\mathrm{C}_{11} \mathrm{H}_{22} \mathrm{O}_{3} \mathrm{Si}$ & 230 & 2.79 & & No report \\
\hline
\end{tabular}


Table 2. Continued.

\begin{tabular}{|c|c|c|c|c|c|c|c|}
\hline & RT & Compound & Formula & $\begin{array}{l}\text { Molecular } \\
\text { weight }\end{array}$ & $\begin{array}{l}\text { Peak } \\
\text { area }\end{array}$ & Structure & Medicinal uses \\
\hline 4 & 24.991 & $\begin{array}{l}\text { Hexadecanoic } \\
\text { acid, methyl } \\
\text { ester }\end{array}$ & C17H3402 & 270 & 20.69 & & $\begin{array}{l}\text { Antioxidant, hypocholest- } \\
\text { erolemic, nematicide, pesti- } \\
\text { cide, antiandrogenic flavor, } \\
\text { hemolytic, 5-alpha reduct- } \\
\text { ase inhibitor, antifibri- } \\
\text { nolytic, lubricant, antialo- } \\
\text { pecic (Selvan and Velavan, } \\
\text { 2015), anti-inflammatory } \\
\text { (Hema et al., 2011), cancer } \\
\text { preventive, hepatopro- } \\
\text { tective, antihistaminic, anti- } \\
\text { eczemic, antiachne, antiar- } \\
\text { thiritic, anticoronary } \\
\text { (Krishnamoorthy and } \\
\text { Subramaniam 2014), } \\
\text { antibacterial, antifungal } \\
\text { (Chandrasekaran et al., } \\
\text { 2011) }\end{array}$ \\
\hline 5 & 28.339 & $\begin{array}{l}9,12- \\
\text { Octadecadienoic } \\
\text { acid }(\mathrm{Z}, \mathrm{Z})\end{array}$ & $\mathrm{C}_{18} \mathrm{H}_{32} \mathrm{O}_{2}$ & 280 & 50.32 & & $\begin{array}{l}\text { Anti-inflammatory, antiar- } \\
\text { thritic, antioxidant, anti- } \\
\text { cancer (Mangunwidjaja et } \\
\text { al., 2006). Hypocholeste- } \\
\text { rolemic, cancer preventive, } \\
\text { hepatoprotective, nematici- } \\
\text { de, Insectifuge, antihista- } \\
\text { minic, Antieczemic, antiac- } \\
\text { ne, 5-alpha reductase } \\
\text { inhibitor, antiandrogenic } \\
\text { anticoronary insectifuge } \\
\text { (Rajeswari et al., 2012). } \\
\text { Antiarteriosclerotic, anti- } \\
\text { anaphylactic, antiprostatic } \\
\text { (Rajeswari and Srinivasan } \\
\text { 2015). }\end{array}$ \\
\hline 6 & 28.449 & $\begin{array}{l}\text { 9-Octadecenoic } \\
\text { acid (Z)-, methyl } \\
\text { ester }\end{array}$ & $\mathrm{C}_{19} \mathrm{H}_{36} \mathrm{O}_{2}$ & 296 & 10.45 & & $\begin{array}{l}\text { Anti-inflammatory, antian- } \\
\text { drogenic, Cancer preven- } \\
\text { tive, dermatitigenic, hypo- } \\
\text { cholesterolemic, 5-alpha } \\
\text { reductase inhibitor, ane- } \\
\text { miagenic, insectifuge } \\
\text { (Rajeswari and Rani 2015), } \\
\text { Antioxidant, anticancer } \\
\text { (Asghar et al. 2011; Hema } \\
\text { et al., 2011) }\end{array}$ \\
\hline 7 & 28.937 & $\begin{array}{l}\text { Heptadecanoic } \\
\text { acid, 16-methyl-, } \\
\text { methyl ester }\end{array}$ & $\mathrm{C}_{19} \mathrm{H}_{38} \mathrm{O}_{2}$ & 298 & 5.78 & & $\begin{array}{l}\text { Used against skin cancer } \\
\text { protein (Elaiyaraja, and } \\
\text { Chandramohan, 2016). } \\
\text { Antioxidant, antimicrobial, } \\
\text { antiinflammatary (Vetha } \\
\text { Merlin Kumari et al., 2016). }\end{array}$ \\
\hline 8 & 37.788 & $\begin{array}{l}\text { Benzenesulfona } \\
\text { mide }\end{array}$ & $\mathrm{C}_{23} \mathrm{H}_{23} \mathrm{NO}_{2} \mathrm{~S}_{2}$ & 409 & 0.87 & & $\begin{array}{l}\text { Antimalarial (Andrews et } \\
\text { al., 2013). }\end{array}$ \\
\hline 9 & 38.276 & $\begin{array}{l}\text { Cyclotrisiloxane, } \\
\text { hexamethyl }\end{array}$ & $\mathrm{C}_{6} \mathrm{H}_{18} \mathrm{O}_{3} \mathrm{Si}_{3}$ & 222 & 0.94 & & $\begin{array}{l}\text { Antimicrobial potential, } \\
\text { antioxidants (Venkatesh et } \\
\text { al., 2014). }\end{array}$ \\
\hline
\end{tabular}


Table 2. Continued.

\begin{tabular}{|c|c|c|c|c|c|c|c|}
\hline & RT & Compound & Formula & $\begin{array}{c}\text { Molecular } \\
\text { weight }\end{array}$ & $\begin{array}{c}\text { Peak } \\
\text { area }\end{array}$ & Structure & Medicinal uses \\
\hline 10 & 40.621 & $\begin{array}{l}\text { N-(tert- } \\
\text { butoxycarbonyl)- } \\
2-(4- \\
\text { methoxyphenyl) } \\
\text { allylamine }\end{array}$ & $\mathrm{C}_{15} \mathrm{H}_{21} \mathrm{NO}_{3}$ & 263 & 1.06 & & $\begin{array}{l}\text { Phytocompound having } \\
\text { liver susceptibility of } \\
\text { reactions (Peter and Venky, } \\
\text { 2012). }\end{array}$ \\
\hline
\end{tabular}

The antioxidant activity of in vitro grown leaf callus of methanolic and ethanolic extracts $S$. kunthiana were assessed by DPPH activity (Figure 2). The DPPH activity of different concentration of methanol and ethanol extract (50$250 \mu \mathrm{g} / \mathrm{ml}$ ) along with standard ascorbic acid is presented in the Table 3 . With the increasing concentrations positive scavenging activity were noted. The percentage of scavenging activity is increasing with the increasing concentration in both the extracts. Among the five different concentrations, both extracts were tested, the higher percentage of inhibition $79.23 \pm 0.37$ was observed in $250 \mu \mathrm{g} / \mathrm{mL}$ of ethanol extract followed by $90.35 \pm 0.54$ methanolic extract against the standard ascorbic acid $91.25 \pm 0.33$ followed by percentage of inhibition $(76.31 \pm 0.34)$ $200 \mu \mathrm{g} / \mathrm{mL}$ of ethanol extract and $87.25 \pm 0.39$ of methanol extract observed in $200 \mu \mathrm{g} / \mathrm{mL}$ against the standard ascorbic acid $89.5 \pm 0.42200 \mu \mathrm{g} / \mathrm{mL}$. The result concludes when compare the scavenging activity percentage of ethanol and methanol, the methanol extract shows higher activity.

Table 3. Antioxidant activity of in vitro callus extract of $S$. kunthiana: DPPH method.

\begin{tabular}{|c|c|c|c|c|c|c|c|}
\hline & \multirow{2}{*}{ Sample } & \multicolumn{5}{|c|}{$\%$ of inhibition } & $\begin{array}{l}\text { Comparison } \\
\text { of activity }\end{array}$ \\
\hline & & $50 \mu \mathrm{g} / \mathrm{mL}$ & $100 \mu \mathrm{g} / \mathrm{mL}$ & $150 \mu \mathrm{g} / \mathrm{mL}$ & $200 \mu \mathrm{g} / \mathrm{mL}$ & $250 \mu \mathrm{g} / \mathrm{mL}$ & \multirow{4}{*}{$\begin{array}{l}\text { Methanol > } \\
\text { Ethanol }\end{array}$} \\
\hline 1 & $\begin{array}{l}\text { Ethanolic } \\
\text { Extract }\end{array}$ & $54.98 \pm 0.33$ & $60.13 \pm 0.32$ & $74.3 \pm 0.34$ & $76.31 \pm 0.34$ & $79.23 \pm 0.37$ & \\
\hline 2 & $\begin{array}{l}\text { Methanolic } \\
\text { Extract }\end{array}$ & $78.16 \pm 0.40$ & $81.03 \pm 0.53$ & $83.28 \pm 0.41$ & $87.25 \pm 0.39$ & $90.35 \pm 0.54$ & \\
\hline 3 & $\begin{array}{l}\text { Ascorbic } \\
\text { Acid }\end{array}$ & $84.31 \pm 0.41$ & $87.23 \pm 0.49$ & $88.16 \pm 0.34$ & $89.5 \pm 0.42$ & $91.25 \pm 0.33$ & \\
\hline
\end{tabular}




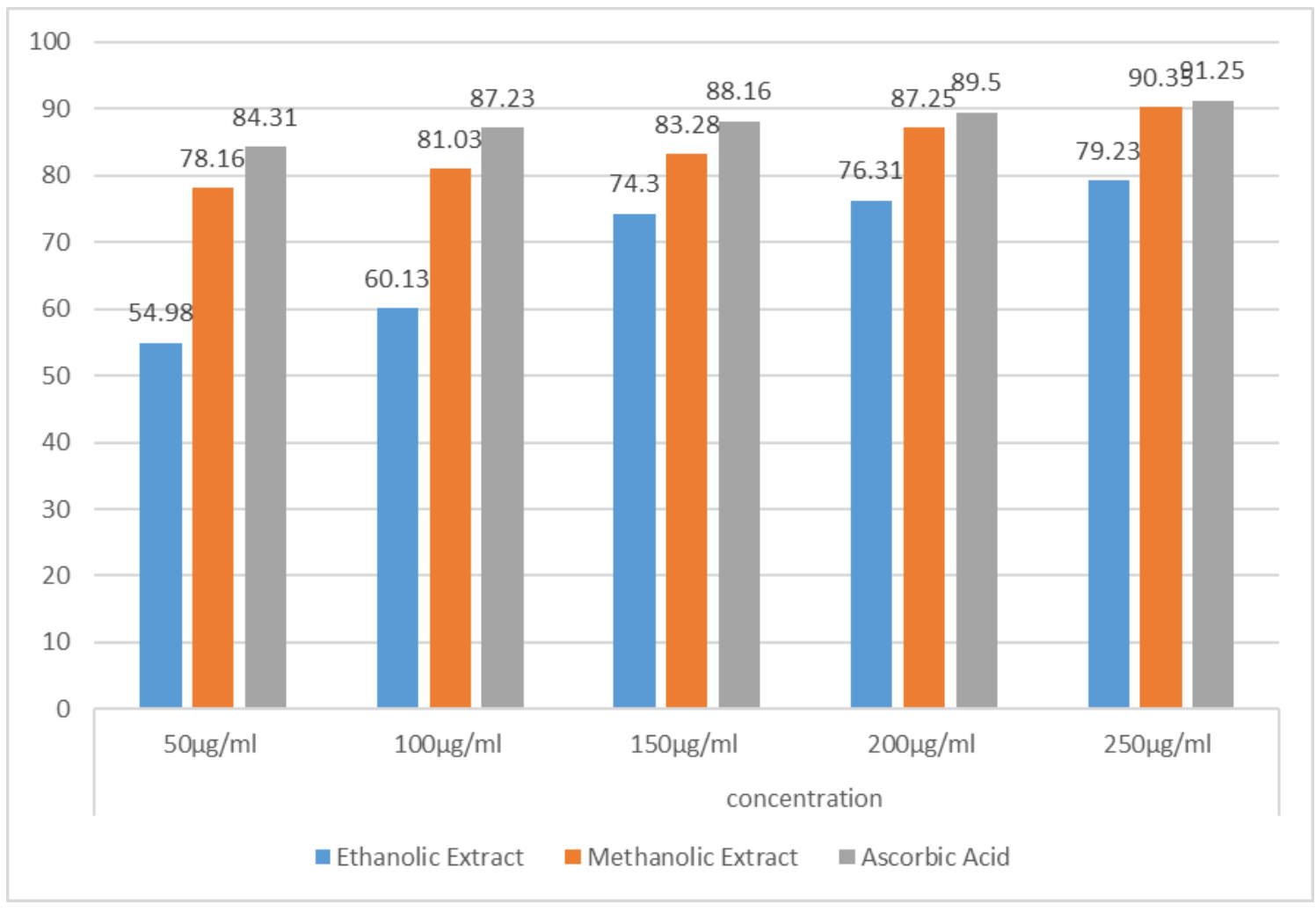

Figure 2. Antioxidant activity of S.kunthiana in vitro callus.

\section{Discussion}

In the present study, preliminary phytochemical screening of in vitro of methanol, ethanol, petroleum ether, chloroform and water extracts of Strobilanthes kunthiana leaf callus. The result concludes that methanolic extract only showed the presence of alkaloids, flavonoids, glycosides, saponins, tannins, steroids, terpenoids and phenols. Similarly, in previous studies it was reported that methanolic flower extract of Strobilanthes kunthiana shows the presence of alkaloids, carbohydrates, phytosterols, tannins, proteins and flavonoids (Singh et al., 2014).

Secondary metabolites of plants serve as defense mechanism against predation by many microorganism, insects and herbivores. These secondary metabolites contribute many biological activities such as anti-inflammatory, antioxidants, antiosteoartritic, analgesic activities, antidiabetic, antimicrobial and heptaprotective (Desu et al., 2011; Singh, 2014).

The presence of alkaloids has pharmacological applications as anesthetics and CNS stimulants (Madziga et al., 2010). Likewise, flavonoids are important group of polyphenols have several proven medicinal properties, such as antioxidants or free radical scavengers (Kar, 2007) and also act as allergies, inflammation, platelet aggregation, microbes, ulcers, hepatoxins, viruses and tumors (Barakat et al., 1993).

Tannins are known to be useful in the treatment of inflamed or ulcerated tissues and act as anticancer (Ruch et al., 1989; Motar et al., 1985).

The phenolic compounds are one of the largest and most ubiquitous groups of plant metabolites (Singh et al., 2007). It possesses biological properties such as antiapoptosis, antiaging, anticarcinogen, antiinflammation, antiatherosclerosis, cardiovascular protection, improvement of endothelial 
function, as well as inhibition of angiogenesis and cell proliferation activities (Han et al., 2007).

Steroids also have antibacterial properties and help in regulating the immune responses (Epand et al., 2007; Shah et al., 2009).

Terpenoids have been found to be useful in the prevention and therapy of several diseases such as cancer, possess antimicrobial, antifungal, antiparasitic, antiviral, anti-allergenic, antispasmodic, anti-hyperglycemic, antiinflammatory and immunomodulatory properties (Rabi and Bishayee, 2009; Wagner and Elmadfa, 2003).

The gas chromatogram shows that the relative concentrations of various compounds are getting eluted as a function of retention time. The peaks height indicate the relative concentrations of compounds present in the plant. Generally, the reliability of medicinal plant for its usage is evaluated by correlating the phytochemical compounds with their biological activities (Belkacem et al., 2013).

The present study is the first report on the GC-MS analysis in Strobilanthes kunthiana callus extract. Totally ten compounds were identified. Most identified compounds have been reported to possess interesting biological activities.

The prevailing major compounds were 9,12-octadecadienoic acid (Z,Z) $(50.32 \%)$ which act as antiinflammatory, antiarthritic, antioxidant, anticancer (Mangunwidjaja et al., 2006) hypocholesterolemic, cancer preventive, hepatoprotective, nematicide, insectifuge, antihistaminic, antieczemic, antiacne, 5-alpha reductase inhibitor, antiandrogenic anticoronary insectifuge (Rajeswari et al., 2012) antiarteriosclerotic, antianaphylactic, antiprostatic (Rajeswari and Srinivasan, 2015). hexadecanoic acid, methyl ester (20.69\%) similar percentage (21.25\%) were reported in Tesium humile (Belakhdar et al., 2015) and it contains many biological activity such as antioxidant, hypocholesterolemic, nematicide, pesticide, antiandrogenic flavor, hemolytic,5-alpha reductase inhibitor, antifibrinolytic, lubricant, antialopecic (Selvan and Velavan 2015), anti-inflammatory (Hema et al., 2011), cancer preventive, hepatoprotective, antihistaminic, antieczemic, antiachne, antiarthiritic, anticoronary (Krishnamoorthy and Subramaniam, 2014), antibacterial, antifungal (Chandrasekaran et al., 2011).

9-Octadecenoic acid (Z)-, methyl ester is reported to have antiinflammatory, antiandrogenic, cancer preventive, dermatitigenic, hypocholesterolemic, 5-alpha reductase inhibitor, anemiagenic, insectifuge (Rajeswari and Rani, 2015 ), antioxidant, anticancer (Asghar et al., 2011; Hema et al., 2011).

Likewise, heptadecanoic acid, 16methyl-, methyl ester is also used against skin cancer protein (Elaiyaraj and Chandramohan 2016), antioxidant, antimicrobial, anti-inflammatary (Vetha Merlin Kumari et al., 2016). 2,6-bis(1, 1dimethylethyl)-4-methyl phenol have antioxidant (Ibtissem et al., 2010) followed by cyclotrisiloxane, hexamethyl reported to have antimicrobial and antioxidants activity (Venkatesh et al., 2014).

$\mathrm{N}$-(tert-butoxycarbonyl)-2-(4methoxyphenyl) allylamine have liver susceptibility of reactions (Peter and Venky, 2012) followed by benzenesulfonamide reported to have antimalarial (Andrews et al., 2013).

The result concludes that the major compound possess antioxidant, anti-inflammatory, anticancer and antimicrobial properties. In present study the stronger methanolic extraction capacity could have been produced number of active constituents responsible for many biological activities. So it is recommended as plant of pharmaceutical importance. However further studies will need to be undertaken its bioactivity and toxicity profile. 
Free radicals have been implicated in many diseases such as cancer, atherosclerosis, diabetes, neurodegenerative disorders and aging $(\mathrm{Yu}, 1994 ;$ Halliwell and Gutteridge, 1999). Plants which contains phenols, flavonoids, vitamins, terpenoids are rich in free radical scavenging and antioxidant activity (Madsen and Bertelsen, 1995; Cai and Sun, 2003).

The plant which shows good source of natural antioxidant activity play a key role in prevention of the chronic and degenerative diseases, such as atherosclerosis, cardiac and cerebral ischema, carcinogenesis, neurodegenerative disorders, diabetic pregnancy, rheumatic disorder, DNA damage, ageing (Uddin et al., 2008; Jayasri et al., 2009).

Our current result showed that the highest inhibition percentage value of methanolic extract of $S$. kunthiana callus was found to be $90.35 \pm 0.54$ than ethanol extract $79.23 \pm 0.37$ against standard ascorbic acid $91.25 \pm 0.33$. The ascorbic acid possesses the ability to scavenge the free radicals in human body. The result revealed that the methanolic extract of callus showed good amount of antioxidants to counteract the damaging effects of free radicals and may protect against mutagenesis.

In contrary other results the significant antioxidant activity were reported in ethyl acetate extract, nbutanol extract of $S$. kunthiana flower and n-hexane extract showed devoid of activity (Singh et al., 2014). Similarly, the crude extract of Psidium guajava showed maximum inhibition of $91 \%$ at 0.5 $\mathrm{mg} / \mathrm{mL}$ which is comparable to $95 \%$ for vitamin C than Carica papaya, Vernonia amygdalina, and Mangifera indica (Ayoola et al., 2008) followed by DPPH scavenging activity of Cassia tora was evaluated at $20-80 \mu \mathrm{g} / \mathrm{mL}$ and the highest as found to be $71.18 \%$ (Sirappuselvi and Chitra, 2012). Likewise, the antioxidant activity of Ipomoea cairica was experimented with DPPH scavenging activity with $82.58 \%$ at $500 \mu \mathrm{g} / \mathrm{mL}$ (Arora et al., 2013).
The result of the present study suggests that $S$. kunthiana can be used as a source of antioxidants for pharmacological preparations which is which is very well evidenced by the present work.

\section{Conclusion}

The present study carried out on the $S$. kunthiana revealed the presence of medicinal active constituents by GCMS. So that those might be utilized for the development of traditional medicines. Based on the results of this study the in vitro callus contains alkaloids, flavonoids, glycosides, saponins, tannins, steroids, terpenoids and phenols. The extract also shows the antioxidant activity. From the above analyses, the possible mechanism of antioxidant activity of all the extracts include reductive ability, hydrogendonating ability, and scavenging of superoxide, nitric oxide and free radicals, which may be due to the presence of phytoconstituents such as flavonoids and polyphenols present in the methanolic in vitro callus extract of $S$. kunthiana.

\section{Acknowledgement}

The authors are thankful to the Management, Secretary and Principal and HOD of Botany, PSG College of Arts \& Science, Coimbatore, Tamil Nadu, for providing necessary infrastructural facilities.

\section{Conflicts of interest}

Authors declare that they have no conflict of interests.

\section{Reference}

Andrews, K T.; Fisher, G. M.; Sumanadasa, S. D.; Skinner-Adams, T.; Moeker, J.; Lopez, M.; Poulsen, S. A. Antimalarial activity of compounds comprising a primary benzene sulfonamide fragment. Bioorganic \& Medicinal Chemistry Letters, v. 23, no. 22, p. 6114-6117, 2013. https://doi.org/ 10.1016/j.bmcl.2013.09.015 
Anonymous I. Indian pharmacopoeia. Delhi: Government of India, Ministry of Health and Welfare, Controller of Publications, 1985.

Anonymous II. Quality control methods of Medicinal plant materials. Geneva: WHO, Delhi: A.I.T.B.S Publishers \& Distributors, 2002.

Arora, S.; Kumar, D.; Shiba. Phytochemical, antimicrobial and antioxidant activities of methanol extract of leaves and flowers of Ipomoea cairica. International Journal of Pharmacy and Pharmaceutical Sciences, v. 5, no.1, p. 198-202, 2013.

Asghar, S. F.; Habib-ur-Rehman; Choudahry, M. I.; Atta-ur-Rahman. Gas chromatographymass spectrometry (GC-MS) analysis of petroleum ether extract (oil) and bio-assays of crude extract of Iris germanica. International Journal of Genetics and Moleular Biology, v. 3, no. 7, p. 95-100, 2011.

Augustine, J.; Josekutty, E. J.; Biju, P. Strobilanthes sainthomiana: A new species of Strobilanthes Blume (Acanthaceae) from Western Ghats, India. Taiwania, v. 62, no. 1, p. 63-66, 2017.

Ayoola, G. A.; Coker, H. A. B.; Adesegun, S. A.; Adepoju-Bello, A. A.; Obaweya, K.; Ezennia, E. C.; Atangbayila, T. O. Phytochemical screening and antioxidant activities of some selected medicinal plants used for malaria therapy in Southwestern Nigeria. Tropical Journal of Pharmaceutical Research, v. 7, no. 3, p. 1019-1024, 2008. https://doi.org/ 10.4314/tjpr.v7i3.14686

Balandrin, M. F.; Kinghorn, A. D.; Farnsworth, N. R. Plant-derived natural products in drug discovery and development: An overview. In: Kinghorn, A D.; Balandrin, M. F. Human medicinal agents from plants. Washington, DC: American Chemical Society, 1993. (ACS Symposium Series). p. 2-12. https://doi.org/ 10.1021/bk-1993-0534.ch001

Barakat, M. Z.; Shahab, S. K.; Darwin, N.; Zahemy, E. I. Determination of ascorbic acid from plants. Annal of Biochem., v. 53, p. 225-245, 1993.

Belakhdar, G.; Benjouad, A.; Abdennebi, E.H. Determination of some bioactive chemical constituents from Thesium humile Vahl. J. Mater. Environ. Sci., v. 6, no. 10, p. 27782783, 2015.

Belkacem, N.; Djaziri, R.; Lahfa, F.; El-Haci, I. A.; Boucherit, Z. Phytochemical screening and in vitro antioxidant activity isolated bioactive compounds from Tridax procumbens Linn. Pakistan Journal of Biological Sciences, v. 16, no. 24, p.1971-1977, 2013. https://doi.org/10.3923/pjbs.2013.1971.19 77

Brand-Williams, W.; Cuvelier, M. E.; Berset, C. Use of free radical method to evaluate antioxidant activity. Lebensmittel Wissenschaft und Technologie, v. 28, p. 2530, 1995. https://doi.org/10.1016/S00236438(95)80008-5

Cai, Y. Z.; Sun, M. Antioxidant activity of betalins from plants of the Amaranthacea. Journal of Agriculture and Food Chemistry, v. 51, no. 8, p. 2288-2294, 2003. https://doi.org/10.1021/jf030045u

Chandrasekaran, M.; Senthilkumar, A.; Venkatesalu, V. Antibacterial and antifungal efficacy of fatty acid methyl esters from leaves of Sesuvium portulacastrum L. Eur. Rev. Med. Pharmcol. Sci., v. 15, no. 7, p. 775780, 2011.

Desu, B. S. R.; Elango, K.; Satish Kumar, M. N.; Suresh, B.; Manimaran. S.; Nanjan, M. J. Invitro anti-inflammatory and antiosteoarthritic activities of Strobilanthes kunthianus and Strobilanthes cuspidatus. International Journal of Research in Pharmaceutical and Biomedical Sciences, v. 1, no. 4, p. 2231-2781, 2011.

Desu, B. S. R.; Elango, K.; Satish Kumar, M. N.; Suresh, B.; Manimaran, S.; Nanjan, M. J. Analgesic activity of Strobilanthes kunthianus and Strobilanthes cuspidatus. International Journal of Research in Pharmaceutical and Biomedical Sciences, v. 3, no. 1, p. 2229-3701, 2012.

Elaiyaraja, A.; Chandramohan, G. Comparative phytochemical profile of Crinum defixum Ker-Gawler leaves using GC-MS. Asian Journal of Pharmaceutical Research and Development, v. 4, no. 3, p. 1-13, 2016. https://doi.org/10.18052/www.scipress.co m/ILNS.46.8

Epand, R. F.; Savage, P. B.; Epand, R. M. Bacterial lipid composition and the antimicrobial efficacy of cationic steroid compounds (Ceragenins). Biochemica et Biophysica Acta (BBA) - Biomembranes, v. 1768 , no. 10 , p. $2500-2509,2007$. https://doi.org/10.1016/j.bbamem.2007.05. 023

Everlyne, I. M.; Darsini, D. T. P.; Yadav, S. A. Unraveling antibiofilm potency of Strobilanthes kunthiana Nees T. Anderson ex 
Benth against throat-infectious methicillinresistant Staphylococcus aureus. Indo American Journal of Pharmaceutical Research, v. 6, no. 6, p. 5707-5716, 2016.

Everlyne, I. M.; Sangilimuthu, A. Y.; Darsini, D. TP. Spectral analyses of the bioactive compounds present in the ethanolic leaf extract of Strobilanthes kunthiana (Nees) T. Anderson ex Benth. Advances in Bioresearch, v. 6, no. 3, p. 65-71, 2015.

Gibbs, R. D. Chemotaxonomy of flowering plants. Montreal: McGill Queen's University Press, 1974. v. 1. https://doi.org/10.2307/ j.ctt1w0 ddx8

Guptha, A. K.; Neeraj, T.; Sharma, M. Quality standards of Indian Medicinal Plants. ICMR, v. 3, p. 9-19, 2005.

Halliwell, B.; Gutteridge, J. M. Free radicals in Biology and Medicine. Oxford: Oxford University Press, 1999.

Han, X.; Shen, T; Lou, H. Dietary polyphenols and their biological significance. Int. J. Mol. Sci., v. 8, no. 9, p. 950-988, 2007. https://doi.org/10.3390/i8090950

Hema, R.; Kumaravel, S.; Alagusundaram, K. GC/MS determination of bioactive components of Murraya koenigii. Journal of American Science, v. 7, no. 1, p. 80-83, 2011.

Hites, R. Gas chromatography mass spectroscopy. In: Settle, F. A. (Ed.). Handbook of instrumental techniques for analytical chemistry. Upper Saddle River, NJ: Prentice Hall PTR, 1997.

Ibtissem, B.; Imen, M.; Souad, S. Dosage of 2, 6-bis (1.1-dimethylethyl)-4-methyl phenol (BHT) in the plant extract Mesembryanthemum crystallinum. Journal of Biomedicine and Biotechnology, v. 2010, Article ID 142486, 5 p., 2010. https://doi.org/10.1155/2010/142486

Jayasri, M. A.; Mathew, L.; Radha, A. A report on the antioxidant activities of leaves and rhizomes of Costus pictus D. Don. International Journal of Integretive Biology, v. 5, no. 1, p. 20-26, 2009.

Kar, A. Pharmaocgnosy and Pharmacobiotechnology. 2. ed. New Delhi: New Age International Limited Publishers, 2007.

Krishnamoorthy, K.; Subramaniam, P. Phytochemical profiling of leaf, stem, and tuber parts of Solena amplexicaulis (Lam.) Gandhi using GC-MS. International Scholarly Research Notices, v. 2014, Article
ID 567409, 13 p., 2014. https://doi.org/ 10.1155/2014/567409

Madsen, H. L.; Bertelsen, G. Spices as antioxidants. Trends Food Science and Technology, v. 6, p. 271-277, 1995. https://doi.org/10.1016/S0924-2244(00) 89112-8

Madziga, H. A.; Sanni, S.; Sandabe, U. K. Phytochemical and elemental analysis of Acalypha wilkesiana leaf. Journal of American Science, v. 6, no. 11, p. 510-514, 2010.

Mangunwidjaja, D. S.; Kardono, S. R.; Iswantini, L. B. S. D. Gas chromatography and gas chromatography-mass spectrometry analysis of Indonesian Croton tiglium seeds. J. Applied Sci., v. 6, no. 7, p. 1576-1580, 2006. https://doi.org/10.3923/jas.2006.1576.1580

Motar, M. L. R.; Thomas, G.; Barbosa Filho, J. M. Effects of Anacardium occidentale stem bark extract on in vivo inflammatory models. J. Ethnopharm., v. 95, no. 2/3, p. 139-142, 1985.

Moylan, E. C.; Bennett, J. R.; Carine, M. A.; Olmstead, R. G.; Scotland, R. W. Phylogenetic relationships among Strobilanthes (Acanthaceae): Evidence from ITS nrDNA, trnL-F cpDNA, and morphology. American Journal of Botany, v. 91, no. 5, p. 724-735, 2004. https://doi.org/10.3732/ajb.91.5.724

Paulsamy, S.; Vijayakumar, K. K.; Murugesan, M.; Padmavathy, S.; Senthilkumar, P. Ecological status of medicinal and other economically important plants in the shola understories of Nilgiris, the Western Ghats. Natural Products Radiance, v. 6, no. 1,p. 5561, 2007.

Peach, K.; Tracey, M. V. Modern methods of plant analysis. Berlin: Springer Verlag, 1956. v. 3.

Peter, P. J.; Venky, V. M. Phytochemical and GC-MS studies Onindigofera linnaei Linn. International Journal of Phytopharmacy Research, v. 2, no. 5, p. 143-148, 2012. https://doi.org/10.7439/ijpp.v2i5.615

Rabi, T.; Bishayee, A. Terpenoids and breast cancer chemoprevention. Breast Cancer Research and Treatment, v. 115, no. 2, p. 223-239, 2009. https://doi.org/10.1007/ s10549-008-0118-y

Rajasekaran, A.; Loganathan, V.; Jaewanth, A.; Jayakar, B. Central nervous activity of Strobilanthes kunthiana leaf. Hamdard Medicus, v. 43, no. 1, p. 38-40, 2000. 
Rajeswari, B.; Srinivasan, M. GC-MS analysis of bioactive components from the ethanolic leaf extract of Flueggea leucopyrus Wild. International Journal of Pharmaceutical Sciences Review and Research, v. 33, no. 1, p. 270-273, 2015.

Rajeswari, G.; Murugan, M.; Mohan, V. R. GCMS analysis of bioactive components of Hugonia mystax L. (Linaceae). Research Journal of Pharmaceutical, Biological and Chemical Sciences, v. 3, no. 4, p.301-308, 2012.

Rajeswari, J.; Rani, S. GC-MS analysis of phytochemical compounds in the ethanolic extract of root of Lawsonia inermis Linn. International Journal of ChemTech Research, v. 7, no. 1, p. 389-399, 2015.

Ruch, R. J.; Cheng, S. J.; Klaunig, J. E. Prevention of cytotoxicity and inhibition of Intercellular communication by antioxidant catechins isolated from Chinese green tea. Carcinogens, v. 10, p.1003-1008, 1989. https://doi.org/10.1093/carcin/10.6.1003

Selvan, P. S.; Velavan, S. Analysis of bioactive compounds in methanol extract of Cissus vitiginea leaf using GC-MS technique. Rasayan Journal of Chemistry, v. 8, no. 4, p. 443-447, 2015.

Shah, B. A.; Qazi, G. N.; Taneja, S. C. Boswellic acids: a group of medicinally important compounds. Natural Product Report, v. 26, p. 72-89, 2009. https://doi.org/10.1039/ B809437N

Singh, B. B.; Das, S.; Maithi, A. Antioxidant Property for lipophilic extract of Strobilanthes kunthiana flowers. Indian Journal of Research in Pharmacy and Biotechnology, v. 2, no. 1, p. 1005-1009, 2014.

Singh, D. N.; Verma, N.; Kulshreshtha, D. K.; Agrawal, A. K. In-vitro antigiardial activity of ethanolic extract and fractions from Phlebophyllum kunthianum. Journal of
Natural Remedies, v. 12 , no. 1, p.68-71, 2012.

Singh, R.; Singh, S. K.; Arora, S. Evaluation of antioxidant potential of ethyl acetate extract/fractions of Acacia auriculiformis. A. Cunn. Food Chem. Toxicol., v. 45, no. 7, p. 1216-1223, 2007.

Sirappuselvi, S.; Chitra, M. In vitro antioxidant activity of Cassia tora Lin. International Research Journal of Biological Sciences, v. 1, no. 6, p. 57-61, 2012.

Treare, G. E.; Evans, W. C. Pharmacognosy. 16. ed. London: Bahive Tinal, 1985. https://doi.org/10.1016/B978-0-70202933-2.00002-2

Uddin, S. N.; Akond, M. A.; Mubassara, S.; Yesmin, M. N. Antioxidant and antibacterial activities of Trema cannabina. Middle-East Journal of Scientific Research, v. 3, no. 2, p. 105-108, 2008.

Venkatesh, R.; Vidya, R.; Kalaivani, K. Gas chromatography and mass spectrometry analysis of Solanum villosum (Mill) (Solanaceae). International Journal of Pharmaceutical Sciences and Research, v. 5, no. 12, p. 52-83, 2014.

Vetha Merlin Kumari, H.; Manickavasakam, K.; Mohan, S. GC-MS analysis of bioactive components of a siddha poly herbal drug Adathoda chooranam. Int. J. RES. Ayurveda Pharm., $\quad$ v. $7, \quad$ no. $2, \quad 2016$. https://doi.org/10.7897/2277-4343.07245

Wagner, K. H.; Elmadfa, I. Biological relevance of terpenoids: overview focusing on mono-, di- and tetraterpenes. Ann. Nutr. Metab., v. 47, p. 95-106, 2003. https://doi.org/10.1159/000070030

Yu, B.P. Cellular defenses against damage from reactive oxygen species. Physiological Reviews, v. 74, no. 1, p. 139-162, 1994. https://doi.org/10.1152/physrev.1994.74.1. 139

License information: This is an open-access article distributed under the terms of the Creative Commons Attribution License, which permits unrestricted use, distribution, and reproduction in any medium, provided the original work is properly cited. 